\title{
Can Goji Berry Extract Attenuate Pancreatic Structural Changes Induced by Patulin Toxin in Male Albino Rats?
}

\section{Original Article}

\author{
Nesreen G. Abd ElHaliem \\ Department of Histology, Faculty of Medicine, Sohag University, Egypt
}

\begin{abstract}
Introduction: Patulin is considered the most common mycotoxins in moldy fruits especially apples and its products like juice and compote. Goji berry (lycium barbarum fruit) is a traditional Chinese herb. It has several biological activities as antioxidant, anti-aging and hypoglycemic properties.

Aim: To demonstrate the toxic effect of patulin on the pancreatic tissue and to evaluate the possible role of goji extract.

Material and Methods: Forty adult male albino rats were divided equally into four groups. Group I served as the control group. Group II received subcutaneous injection of $2 \mathrm{ml} / \mathrm{kg} /$ day goji extract for four weeks. Group III received subcutaneous injection of patulin $0.2 \mathrm{mg} / \mathrm{kg} /$ day for four weeks. Group IV received patulin and goji extract with the same previous doses for four weeks. Histological and immunohistochemical studies were done.

Results: The administration of patulin led to degenerative changes in the pancreas. There was a significant increase in caspase-3 positive cells in both acini and islets of Langerhans. Ultrastructural examination revealed heterochromatic nuclei, cytoplasmic vacuoles and few secretory granules in acinar cells. The $\beta$ cells of the islets exhibited a significant decrease in the area percentage and intensity of insulin positive cells. Goji extract could effectively improve these histological changes.

Conclusion: Patulin toxicity affected both exocrine acini and $\beta$ cells of islets of Langerhans. The goji extract had a protective role on this toxicity.
\end{abstract}

Keywords: Caspase-3, goji extract, insulin, islets of langerhans, lycium barbarum, patulin

Revised: 09 December 2016, Accepted: 06 July 2017

Corresponding Author: Nesreen Gamal Soliman, Assistant Professor, Faculty of Medicine, Sohag University

Tel.: 00201006566743, E-mail: nesreengamal2000@yahoo.com

ISSN: 1110-0559, 2017, Vol 40, , No. 2

\section{INTRODUCTION}

Patulin is a common mycotoxin affecting our health. It is a secondary metabolite of different types of fungal species, especially Aspergillus and Penicillium ${ }^{[1]}$. It is found in apples and food products derived from apples such as juice and compotes. Despite many trials was done to reduce its levels in all stages of the apple product processes, the occurrence of this mycotoxin is still high throughout the world $^{[2]}$. Numerous surveys of patulin concentration in apple products have been done in different countries over the last years. They proved that patulin concentration more than the recommended daily level allowed by food and drug administration organization in apple juice samples collected worldwide $^{[3,4]}$. A better understanding of mechanism of its toxicity on different organs would help to antagonize its effect. Previous studies reported its toxic effect on some endocrine organs as thyroid and Leydig cell of testes ${ }^{[5]}$. The toxic effects of patulin have been studied thoroughly, and it possesses genotoxic and neurotoxic through binding to sulphydryl groups in proteins and peptides ${ }^{[6]}$. Besides, patulin might have diabetogenic effect ${ }^{[7]}$. Its toxicity is associated with the formation of reactive oxygen species and depletion of cellular glutathione which is a main intracellular antioxidant, and induced oxidative DNA damage and cell death ${ }^{[8]}$. It was proved that oxidative stress is an apoptosis inducer ${ }^{[9]}$.

Apoptosis makes a major role in the development and survive of the organisms ${ }^{[10]}$. It is manifested by a group of biochemical and morphological changes, including chromatin condensation, DNA fragmentation and caspase activation. Caspase (cysteinyl aspartate proteinase) has a great role in the maintenance of this process ${ }^{[11]}$. Previous studies had been found that its activation is the key of the apoptotic cell death ${ }^{[12]}$. A variety of caspases affect DNA structure regulation, replication and repair. Caspase-3 cleavage has been obtained under oxidative stress in different pathological conditions ${ }^{[13]}$.

Traditional medicine concerns with the active ingredients of different plants for curing diseases ${ }^{[14]}$. Lycium barbarum fruit (Wolfberry or Goji berry) is well-known in traditional Chinese herbal medicine and 
nowadays it has been widely used as a popular functional food. It can enter in the manufacture of variable kinds of healthy products and foods as medicinal beverages and drinks, and dietary soups ${ }^{[15]}$. It contains several functional components including carotenoids, flavonoids and polysaccharides. They have several biological and pharmacological properties, such as antioxidant, hypolipedimic, anti-aging, hypoglycemic, antitumor, anti-osteoporosis and immunomodulation. Recent researches have focused on the importance of flavonoids because of their major roles in biological and antioxidant activities ${ }^{[16]}$

\section{MATERIAL AND METHODS}

\section{Chemicals}

Patulin (4-hydroxy-4H-furo [3, 2-c $]$ pyran-2 (6H)-one) was obtained from Sigma Chemical Company as a powder vehicle. Goji berry was purchased as dried fruit and the ethanolic extract was prepared at Faculty of Science Sohag University. A 5 g sample was extracted with $100 \mathrm{~mL} 80 \%$ ethanol at $35^{\circ} \mathrm{C}$ for $24 \mathrm{hr}$ in a shaking bath after cooling the extract was centrifuged at $3,000 \mathrm{rpm}$ for $10 \mathrm{~min}$, filtered and stored at $4{ }^{\circ} \mathrm{C}$ until use within $24 \mathrm{hr}{ }^{[17]}$.

\section{Experimental design and animals}

Forty male albino rats (200- $250 \mathrm{gm})$ were kept at $22{ }^{\circ} \mathrm{C}$ and given standard rat diet and had free access to tap water. They were kept in this environment for one week before the experiment. All procedures used in this experiment were approved with the local Ethics Committee. The animals were divided randomly into four groups (10 rats each in two cages) in a ventilated animal room in Sohag animal house and were subjected to the following schedule of treatments ${ }^{[18]}$ :

Group I (control group) was subcutaneously injected with $2 \mathrm{ml} / \mathrm{kg} /$ day distilled water for four weeks.

Group II was subcutaneously injected with $2 \mathrm{ml} / \mathrm{kg} /$ day goji extract for four weeks.

Group III was subcutaneously injected with patulin $0.2 \mathrm{mg} / \mathrm{kg} /$ day four weeks.

Group IV was subcutaneously injected with $2 \mathrm{ml} /$ $\mathrm{kg} /$ day of goji extract and after one hour they received patulin as the previous dose for four weeks.

The pancreas of each animal was dissected out after $24 \mathrm{hs}$ from the last dose, then washed with saline, divided into two halves to be processed for light and electron microscopic examination.

\section{Light microscopic studies:}

The specimens were fixed in $10 \%$ neutral formalin. Then they were processed for preparation of serial paraffin sections of $5 \mu \mathrm{m}$ thickness that was subjected to ${ }^{[19]}$ :

1- H\&E staining.

2- Immunohistochemistery for detection of:

activated caspase-3 (purchased as anti-caspase-3 Ab-4, rabbit polyclonal antibody, Thermo Scientific, Fremont, California, USA) for detection of apoptotic pancreatic cells. The reaction appeared as brownish cytoplasmic granules with some nuclear staining.

Insulin (purchased as anti-insulin Ab-6 primary antibody: mouse monoclonal antibody,; Thermo Scientific, Fremont, California, USA). The reaction appeared as brownish cytoplasmic granules.

The immunohistochemical staining was performed by using the avidin-biotin peroxidase technique. Sections were incubated for 60 at $4^{\circ} \mathrm{C}$ min with a 1: 100 dilution of the primary antibody. Finally they counterstained with Mayer's hematoxylin, dehydrated, cleared, and mounted. Negative controls were performed after omitting the primary antibody. In case of caspase- 3 palatine tonsil specimens were used as positive controls.

\section{Transmission electron microscopic study:}

The specimens were fixed at $4{ }^{\circ} \mathrm{C}$ in phosphate buffered 2.5\% glutaraldehyde $(\mathrm{pH} 7.3)$ and postfixed in cold osmium tetraoxide thereafter, embedded in epon. Semithin sections ( $1 \mu \mathrm{m}$ thick) were cut and stained with $1 \%$ toluidine blue, and examined by a light microscope for proper orientation. Ultrathin sections $(80-90 \mathrm{~nm})$ were stained with uranyl acetate for $10 \mathrm{~min}$ and lead citrate for $5 \mathrm{~min}$. They were examined and photographed using a JEOL JEM 1010 electron microscope (JEOL Ltd, Tokyo, Japan) in the Electron Microscope Research Laboratory of the Histology and Cell Biology Department, Faculty of Medicine, Sohag University, Egypt.

\section{Morphometric and statistical studies:}

(1) Area percentage and density of the expression of insulin positive immunoreactive $\beta$ cells /islet was determined.

(2) The number of caspase-3 positive immunoreactive cells was counted.

All measurements were taken using the image analyzer (Leica Q 500 MC program, Wetzlar, Germany) 
in the Histology Department, Faculty of Medicine, Sohag University, Egypt. Examinations were performed in 5 high-power fields/five different sections in each rat. Statistical analysis was performed by using a paired t-test (SPSS program, version 17, IBM Corporation, Somers, New York, USA) in the form of mean \pm SE (standard error).

\section{Light microscopic examination:}

\section{The Control (group I):}

The pancreatic tissue consisted of lobules separated by thin connective tissue septa. Each lobule contained variable numbers of exocrine acini and pale non capsulated islets of Langerhans embedded within. The intralobular and interlobular ducts were found within the exocrine acini and connective tissue septa, respectively. The acinar cells were pyramidal in shape, with basal vesicular nuclei, and apical acidophilic secretory granules. The islets appeared well delineated and they were composed of closely arranged cellular cords separated by small blood sinusoids. The cells showed rounded vesicular nuclei and pale acidophilic cytoplasm (Fig. 1).

Immunostained sections with anti-insulin showed moderately positive cells in the islets core. The positive reaction appeared as dark brown cytoplasmic granules (Fig. 2). Few positive caspase-3 immunostained cells in the islets of Langerhans and pancreatic acini were observed. The positive reaction was in the form of cytoplasmic or nuclear brownish coloration (Fig. 3).

\section{Ultrastructural examination:}

The exocrine acinar cells had rounded basal euchromatic nuclei. The cytoplasm showed contained rough endoplasmic reticulum cisternae, mitochondria and apical electron-dense secretory granules (Fig. 4). B cells of islets of Langerhans contained rounded euchromatic nuclei, Golgi bodies, rounded mitochondria, parallel arrays of rough endoplasmic reticulum, and numerous secretory granules. These granules showed variable electron-dense cores surrounded by a wide electronlucent halo (Fig. 5).

Goji extract treated group (group II) showed similar histological and immunohistochemical results as compared to the control group I.

\section{Four weeks patulin treated (group III):}

Light microscopic examination revealed degenerative changes in both exocrine and endocrine part of pancreas. Some acinar cells had cytoplasmic vacuoles, pyknotic nuclei and increased basophilia. Some islets of Langerhans cells showed deeply acidophilic vacuolated cytoplasm and pyknotic nuclei (Fig. 6). Insulin immunostained sections revealed decrease in both number and intensity of the immune-reaction in the pancreatic islets as compared with the control group (Fig. 7). There were numerous caspase-3 positive cells in both acini and islets of Langerhans (Fig. 8).

The ultrastructural examination confirmed the light microscopic findings. Some acinar cells exhibited heterochromatic irregular nuclei, dilated RER cisternae, vacuoles and few zymogen granules (Fig. 9). Apoptotic bodies containing closely packed but structurally intact RER and other organelles were frequently seen. Occasionally nuclear fragments were noticed. They were phagocytosed by the adjacent acinar cells and could not be distinguished from autophagic vacuoles (Fig. 10). Some acinar cells were binucleated and engorged with RER cisternae and few granules. These changes were associated with disruption of junctional complexes with adjacent acinar cells and wide intercellular spaces (Fig. 11). Some $\beta$ cells showed irregular heterochromatic nuclei and electron dense cytoplasm which exhibited reduced number of organelles. Moreover, convolution of the cell surface was seen (Fig. 12).

\section{Combined goji extract and patulin treated group IV:}

The architecture of exocrine pancreas and islets of Langerhans was more or less similar to the control. Mitotic figures and binucleated cells were noticed in some exocrine acini. Most of the islet cells had vesicular nuclei and acidophilic cytoplasm while few cells contained small pyknotic nuclei (Fig. 13). Insulin immunostained sections revealed that both number and intensity of the immunopositive cells was more or less similar to the control group (Fig. 14). There were few caspase-3-immunopositive cells in both acini and islets of Langerhans as compared to group III (Fig. 15).

The ultrastructural examination observed that most of the acinar cells and their organelles appeared more or less similar to those in the control group. Some of them still showed small vacuoles and some dilated RER cisternae (Fig. 16). $\beta$ cells contained euchromatic nuclei, rough endoplasmic reticulum cisternae, Golgi bodies and numerous granules (Fig. 17). 


\section{RESULTS}

\section{Morphometric and quantitative statistical results:}

The mean number of caspase-3 positive cells in both acini and islets of Langerhans revealed a significant increase in patulintreated groups III as compared to group I and II. However, group
IV exhibited a significant decrease as compared to group III. The mean value of area percentage and density of insulin positive cells showed a significant decrease in patulin-treated group III as compared with groups I and II. On the other hand, group IV exhibited non significant changes as compared to group I and II (Table 1 and Histogram 1).

Table 1: Mean \pm SE of area $\%$ and density of insulin granules in immunopositive cells and number of caspase-3 immunoreactive cells in the islets of Langerhans and pancreatic acinis

\begin{tabular}{|c|c|c|c|c|}
\hline & $\begin{array}{l}\text { Area } \% \text { of insulin } \\
\text { positive cells }\end{array}$ & $\begin{array}{l}\text { Density of insulin } \\
\text { granules }\end{array}$ & $\begin{array}{l}\text { caspase- } 3 \text { positive } \\
\text { cells in islets of } \\
\text { the Langerhans }\end{array}$ & $\begin{array}{l}\text { caspase- } 3 \text { positive cells } \\
\text { in pancreatic acini }\end{array}$ \\
\hline Group I & $6.30 \pm 0.41$ & $15.35 \pm 0.9$ & $0.15 \pm 1.3$ & $0.18 \pm 0.9$ \\
\hline Group II & $7.32 \pm 2.5$ & $14.84 \pm 3.1$ & $0.20 \pm 1.2$ & $0.17 \pm 2.7$ \\
\hline Group III & $2.06 \pm 0.62 *$ & $6.19 \pm 4.2^{*}$ & $37.21 \pm 2.4^{*}$ & $54.39 \pm 2.6^{*}$ \\
\hline Group IV & $8.91 \pm 1.2$ & $16.17 \pm 0.85$ & $4.21 \pm 0.5$ & $6.91 \pm 1.3$ \\
\hline
\end{tabular}

* P value $\leq 0.05$ significant change in comparison to control group. SE (standard error)

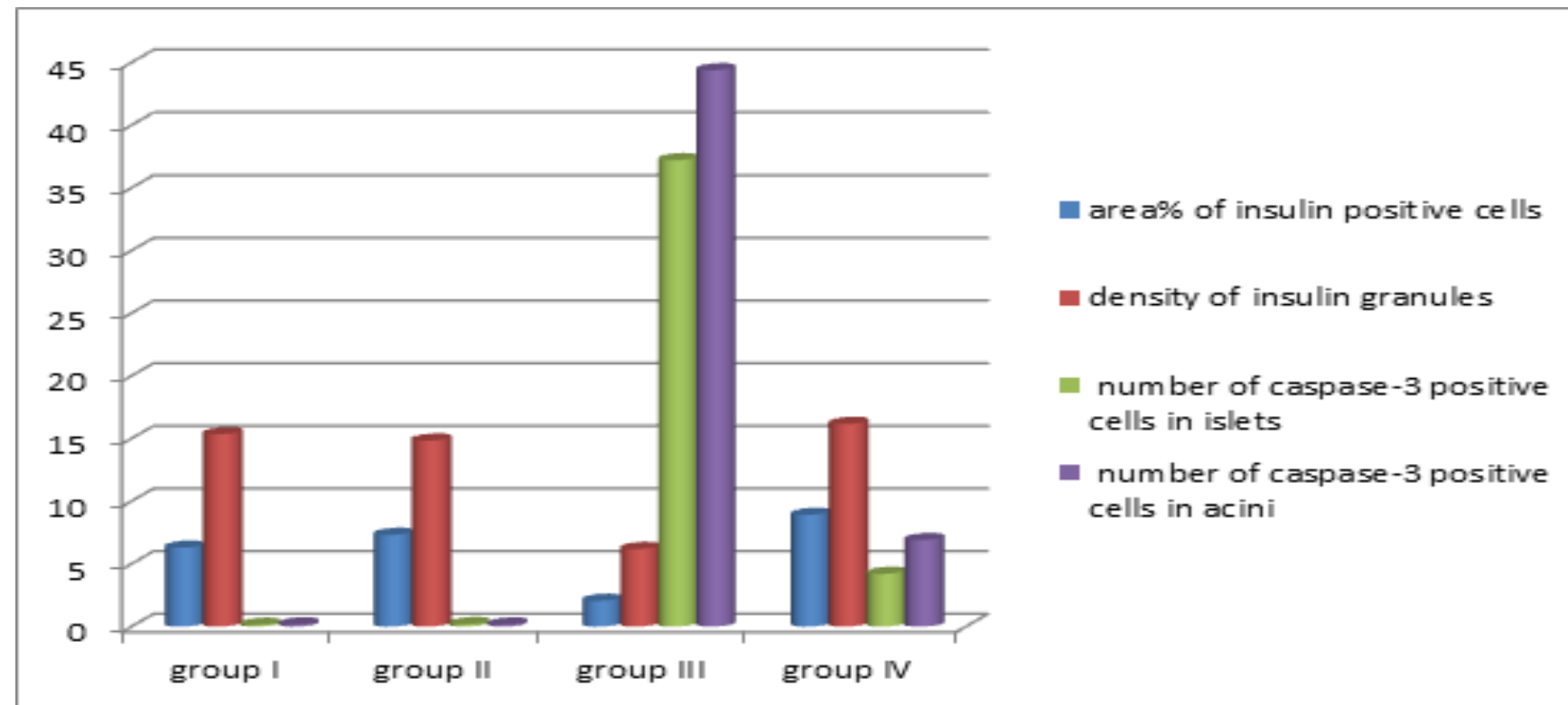

Histogram 1. 


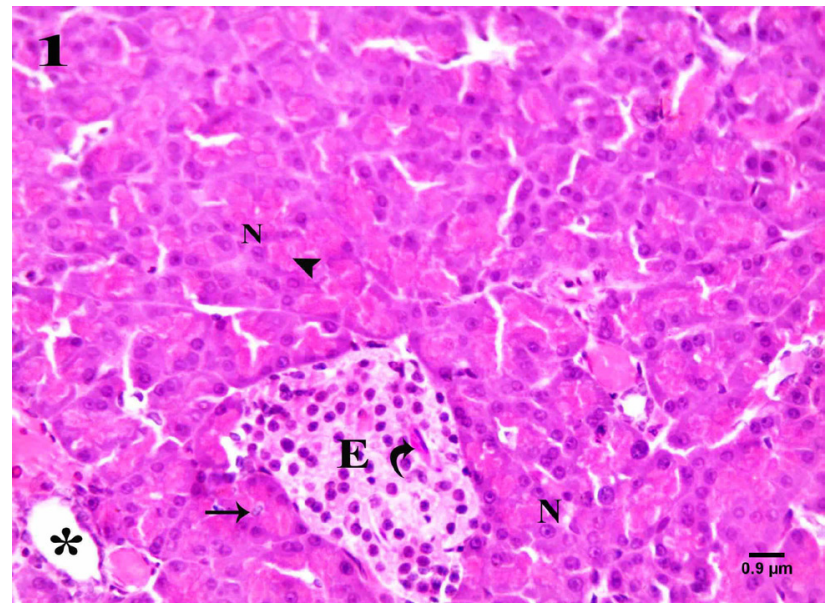

Fig. 1: A photomicrograph of a control pancreas GI showing serous acini and the islets of langerhans. The acinar cells contain vesicular nuclei with prominent nucleoli $(\mathrm{N})$, zymogen granules (arrowhead) and centroacinar cells (arrow). Cell cords of the islet (E) and blood sinusoids (curved arrow) are seen. Note: the interlobular ducts $(*)$. H\&E (Scale bar $0.9 \mu \mathrm{m}$ ).

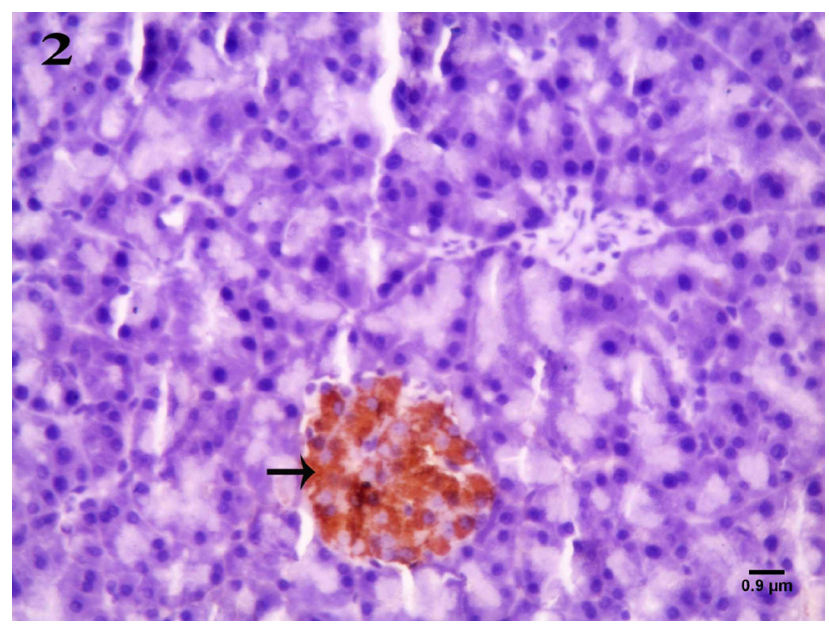

Fig. 2: A photomicrograph of control pancreas GI showing insulin positive brownish cytoplasmic immunoreaction in the most of islet of Langerhans cells (arrow).

Anti insulin (Scale bar $0.9 \mu \mathrm{m}$ ).

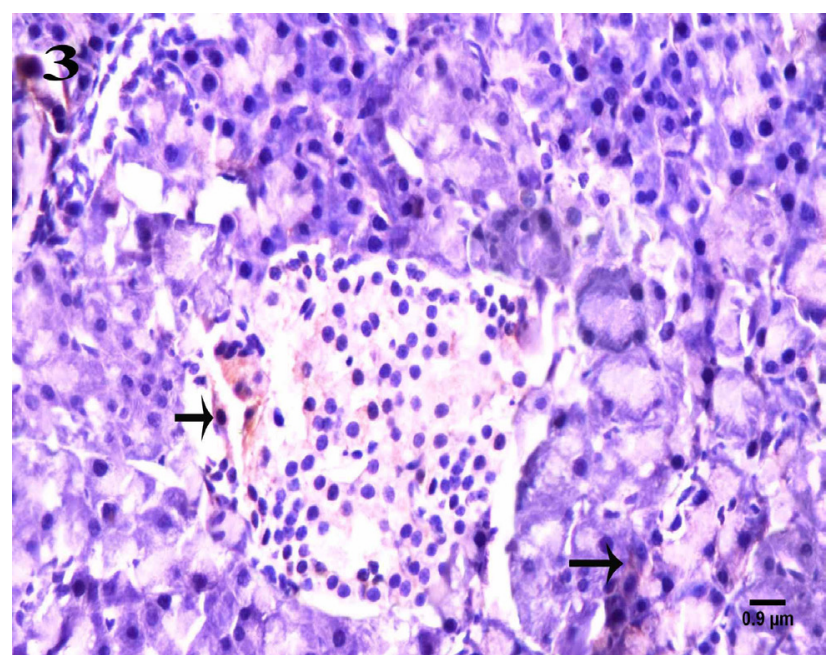

Fig. 3: A photomicrograph of control pancreas GI showing few caspase-3 positive immunostained cells in acini and islet of Langerhans (arrow). The reaction is either nuclear or cytoplasmic. Anti caspase-3 (Scale bar $0.9 \mu \mathrm{m}$.

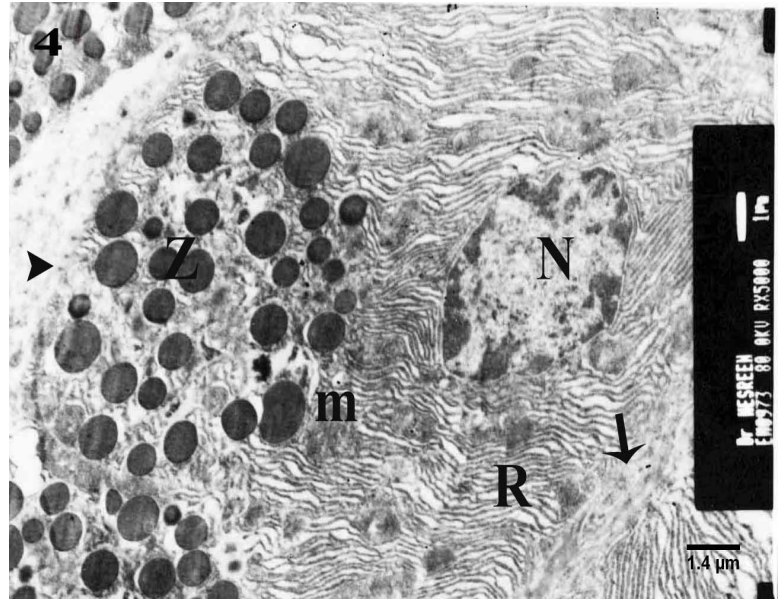

Fig. 4: An electron micrograph of control acinar cell GI showing the cytoplasm contains euchromatic nucleus $(\mathrm{N})$, longitudinally arranged RER (R), mitochondria (m) and zymogen granules ( $\mathrm{Z}$ ). Note: thin basement membrane (arrow) and short microvilli (arrowhead) project towards the narrow lumen. TEM (Scale bar $1.4 \mu \mathrm{m}$ )

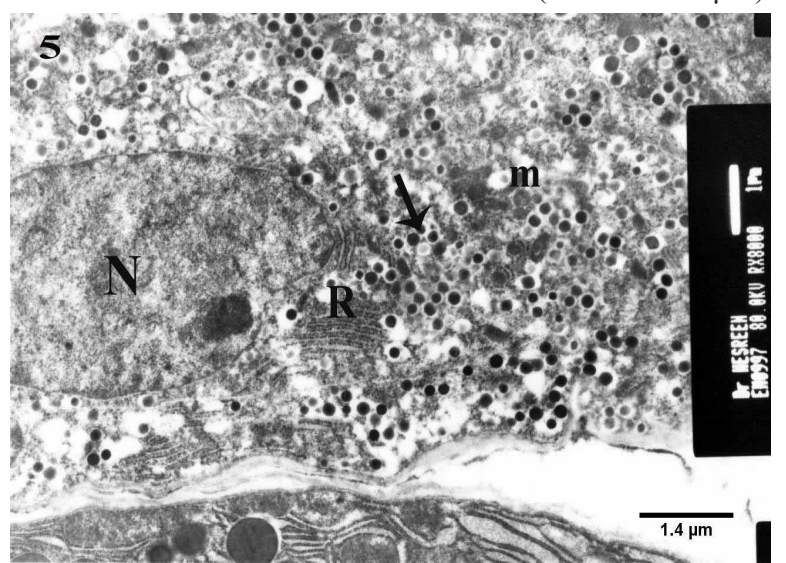

Fig. 5 : An electron micrograph of control $\beta$ cell of islets of Langerhans GI showing euchromatic nuclei $(\mathrm{N})$ with prominent nucleolus and secretory granules with variable electron-dense cores and wide halos (arrow), Note: round mitochondria (m) and RER (R). $\quad$ TEM (Scale bar $1.4 \mu \mathrm{m}$ )

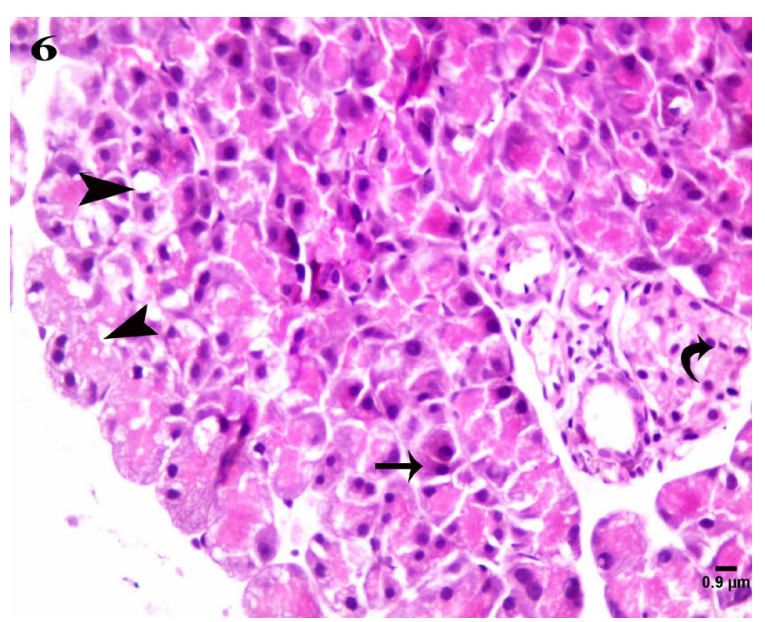

Fig. 6: A photomicrograph of patulin treated pancreas GIII showing cytoplasmic vacuoles in some acinar cells (arrowhead). Others with dense nuclei and high basophilic cytoplasm are also seen (arrow). Some islet cells have dense nuclei and vacuolated cytoplasm (curved arrow).

H\&E (Scale bar $0.9 \mu \mathrm{m})$ 


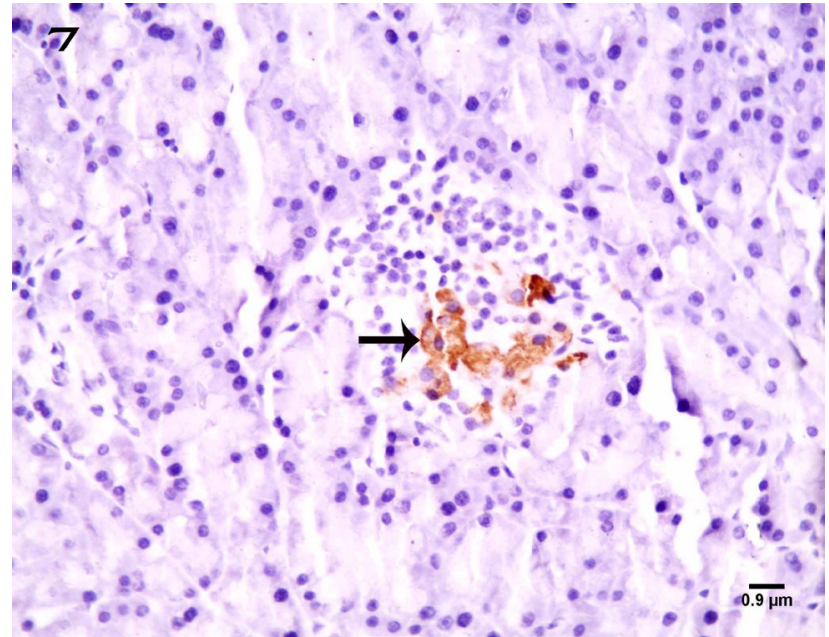

Fig. 7:A photomicrograph of patulin treated pancreas GIII showing apparent decrease in the number and intensity of the insulin positive immunostained cells as compared to control group (arrow).

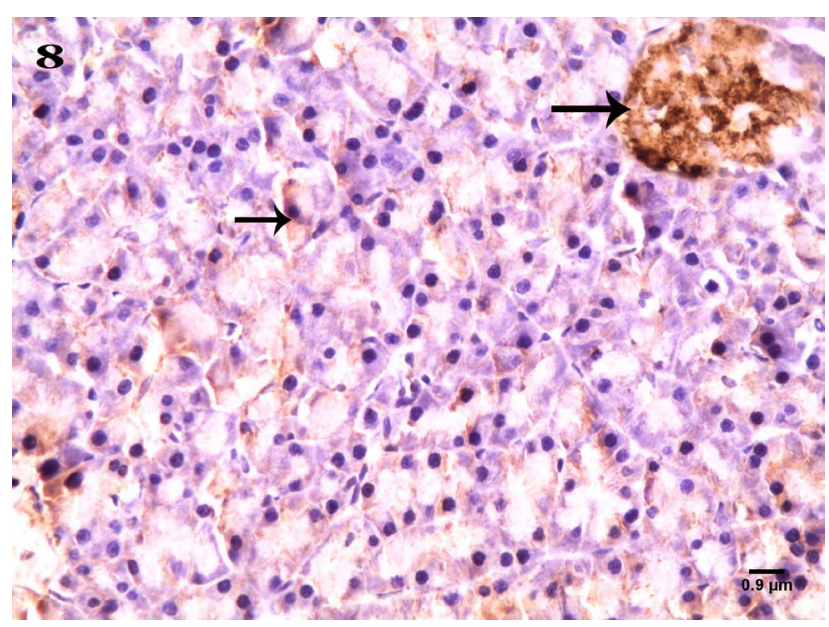

Fig. 8: A photomicrograph of patulin treated pancreas GIII showing numerous caspase-3 positive immunostained cells in both acinar cells and islet of Langerhans (arrow). Anti-caspase-3 (Scale bar $0.9 \mu \mathrm{m})$.

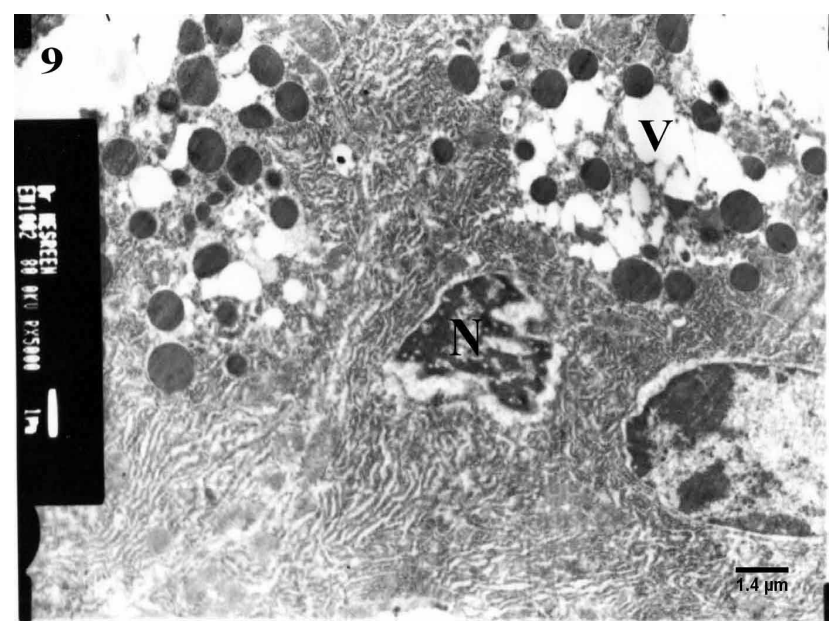

Fig. 9: An electron micrograph of patulin treated pancreas of group III showing heterochromatic fragmented nucleus $(\mathrm{N})$ in the acinar cell is seen. Numerous variable sized vacuoles (V) and few secretory granules are also observed.

TEM (Scale bar $1.4 \mu \mathrm{m})$

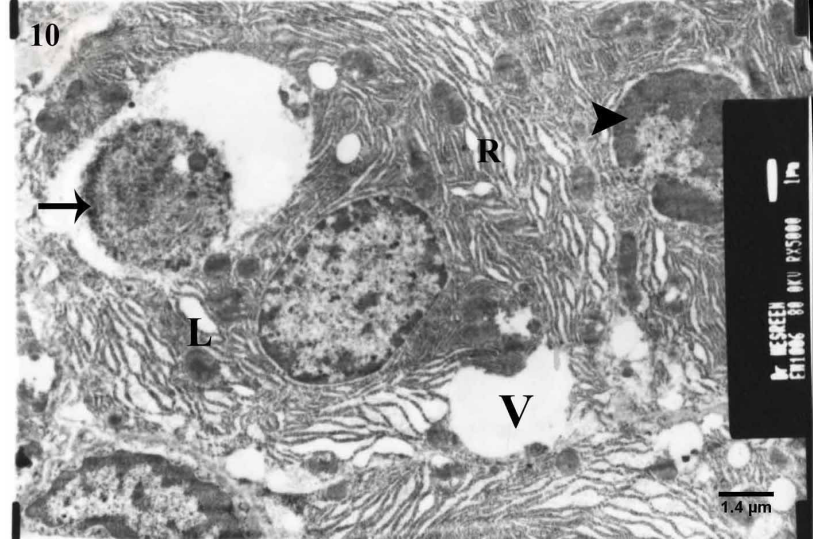

Fig. 10: An electron micrograph of patulin treated pancreas of group III showing pancreatic acinar cell contains apoptotic body (arrow) without nuclear material within the phagolysosome. lysosomese (L), dilated RER cisternae (R) and large vacuoles (V) are also seen in the cytoplasm. The adjacent cell shows nuclear changes as aggregated heterochromatin against nuclear envelope (arrowhead).

TEM (Scale bar $1.4 \mu \mathrm{m}$ )

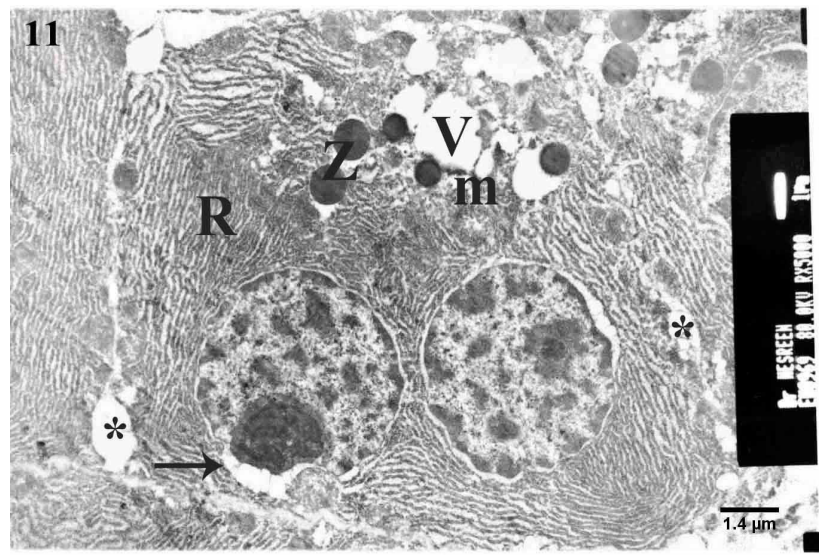

Fig. 11: An electron micrograph of patulin treated pancreas of group III showing a binucleated acinar cell with prominent nucleoli and dilated perinuclear endoplasmic reticulum cisternae (arrow) is noticed. Its cytoplasm contains RER cisternae (R), few secretory granules $(\mathrm{Z})$, mitochondria $(\mathrm{m})$ and vacuoles $(\mathrm{V})$. Note: disruption of junctional complexes with adjacent acinar cells and widening in the intercellular spaces $(*)$.

TEM (Scale bar $1.4 \mu \mathrm{m})$

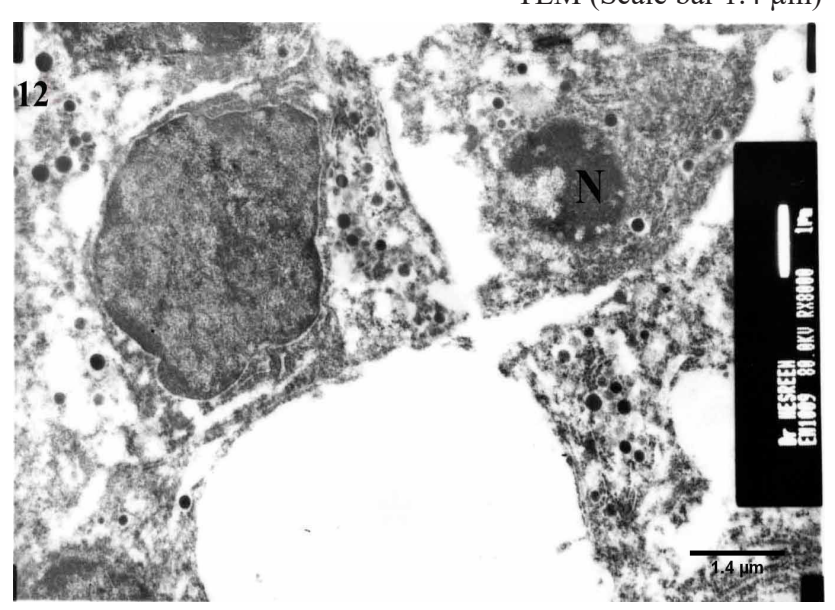

Fig. 12: An electron micrograph of patulin treated pancreas of group III showing $\beta$ cell of islet on the right of the figure contains intended heterochromatic nucleus (N) and electron dense cytoplasm with few secretory granules. Note: convoluted cell membrane. TEM (Scale bar $1.4 \mu \mathrm{m})$ 


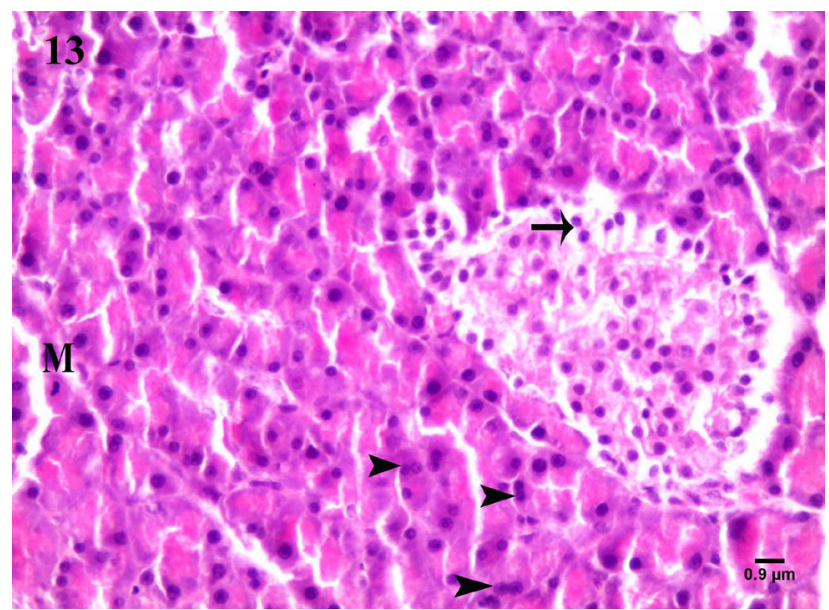

Fig. 13: A photomicrograph of combined treated pancreas group IV showing most of islet cells is more or less similar to the control group (arrow). Mitotic figures (M) and binucleated cells are frequently seen in the exocrine acini (arrowhead).

H\&E (Scale bar $0.9 \mu \mathrm{m}$ )

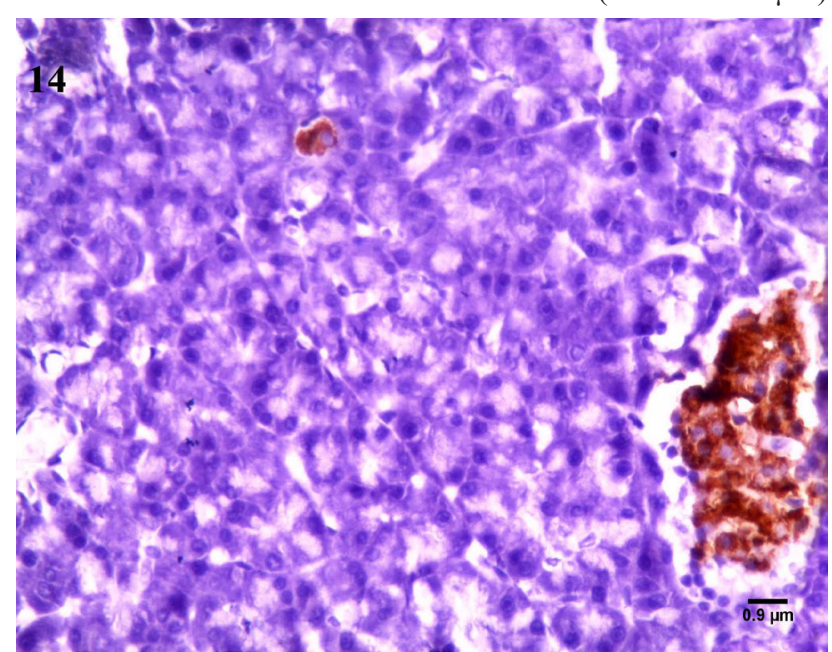

Fig. 14: A photomicrograph of combined treated pancreas group IV showing insulin immunostained cells are more or less similar to the control. Anti insulin (Scale bar $0.9 \mu \mathrm{m}$ )

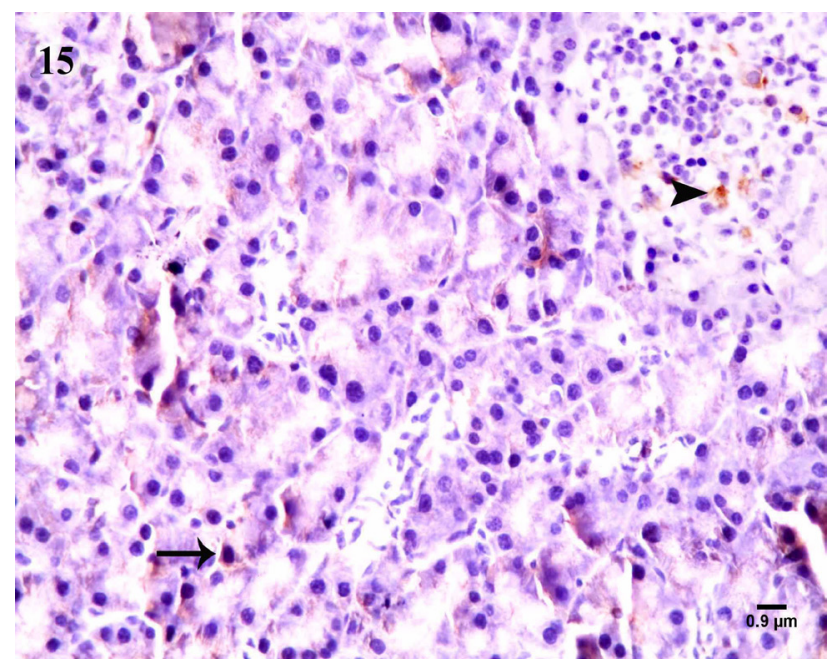

Fig. 15: A photomicrograph of combined treated pancreas group IV showing few caspase-3 positive immunostained cells in both acini (arrow) and the islets (arrowhead) are noticed.

Anti caspase-3 (Scale bar $0.9 \mu \mathrm{m}$ ).

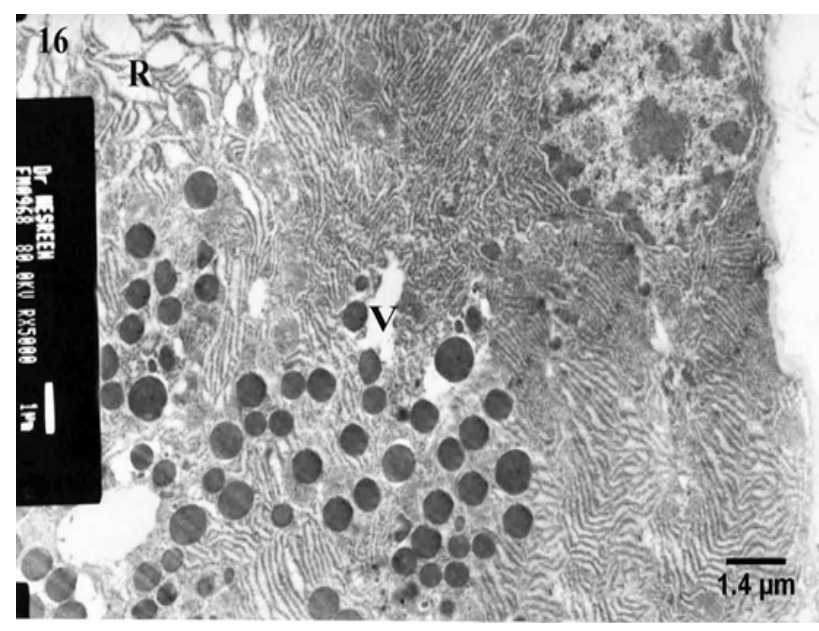

Fig. 16: An electron micrograph of the exocrine acini of group IV showing an acinar cell with their organelles and nucleus is more or less similar to the control group apart from some vacuoles (V) and dilated RER cisternae (R).

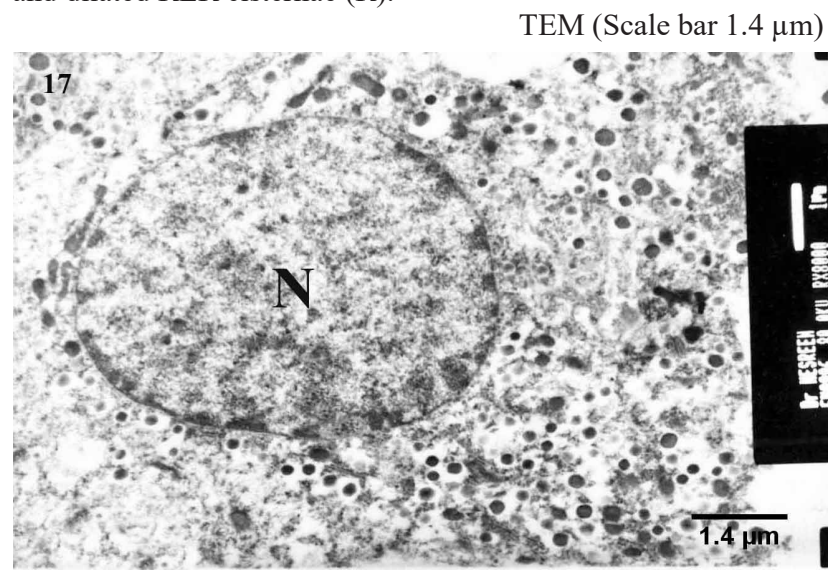

Fig. 17: An electron micrograph of combined treated pancreas of group IV showing $\beta$ cell of islets of Langerhans contains an euchromatic nucleus $(\mathrm{N})$, numerous secretory granules. Their organelles are more or less similar to control.

TEM (Scale bar $1.4 \mu \mathrm{m}$ )

\section{DISCUSSION}

This retrospective histological and immunohistochemical study was designed to evaluate the pathogenesis of pancreatic toxicity induced by patulin exposure and the role of goji extract to eliminate its toxicity The relationship between the endocrine and exocrine parts of the pancreas is a complex one because of the close anatomical and functional links. The impairment of the endocrine part of the pancreas has a marked effect upon its exocrine component. It was stated that islet hormones regulate acinar cell functions as they reach to them with portal vessel system from closed islets ${ }^{[20]}$.

In this work, patulin administration was associated with apoptotic changes in acinar and $\beta$ cells. Light microscopic examination revealed pyknoti nuclei, cytoplasmic vacuoles and a significant increase in the number of caspase- 3 positive cells in the acini and islets of Langerhans. Ultrastructural findings confirmed these results as the appearance of heterochromatic nuclei, apoptotic bodies 
and dilated RER cisternae in acinar cells. Most of $\beta$ cells exhibited convolution of the cell membrane, electron dense cytoplasm, irregular heterochromatic nuclei and few secretory granules. These changes might be due to DNA damage secondary to lipid peroxidation, excess reactive oxygen species and glutathione depletion causing cell cycle $\operatorname{arres}^{\left[{ }^{[8]}\right.}$. In agreement with this hypothesis previous studies found that lipid peroxides react with $\mathrm{Fe} 2$ in the nucleus to generate the alkoxyl radical which attacks DNA (21). Similar results were found in skin cell line after patulin exposure. It was proved that patulin mediated apoptosis through mitochondrial pathway, induction of cytochrome $\mathrm{C}$ protein and activation of caspase-3. Moreover, it enhanced the expression of p53 and Bax proteins ${ }^{[22]}$. On the other hand, patulin could increase the release of tumor necrosis factor- $\alpha$ and decrease total antioxidant levels that led to DNA strands breakdown and increase in the number of the apoptotic cells ${ }^{[23]}$. On the contrary, prolonged exposure to patulin led to cell proliferation and tumor promotion ${ }^{[24]}$.

EM examination of some acini revealed disruption in the intercellular junction between the acinar cells. This could obtain secondary to high reactivity of patulin for sulphydryl groups in the cell membrane proteins and peptides ${ }^{[25]}$. In concomitant to this suggestion Mahfoud et al (2002) proved that patulin could decrease the transepithelial resistance, and disorganize the tight junctions as well as inhibition of protein tyrosine ${ }^{[26]}$. Other acinar cells exhibited highly basophilic cytoplasm, two nuclei with prominent nucleoli, few zymogen granules and RER proliferation. The presence of these features together might represent a state of hyperactivity that compensates the decrease in protein synthesis secondary to cell deaths. Similar explanation was reported after pancereatic injury by other toxin ${ }^{[27]}$. In accordance to this suggestion, Riley and Showker found that patulin caused calcium ion influx ${ }^{[28]}$. This activates ion channels and stimulates exocytosis of zymogen granules and the secretion of the primary fluid from acinar cells ${ }^{[29]}$.

We observed a significant decrease in both density and area percentage of insulin positive immunostained cells. This could be due to apoptotic cell death and low secretory activity which were confirmed ultrasructurally and immunohistochemically.

Previous researches demonstrated that patulin could inhibit RNA and protein synthesis in $\beta$ cells of islets of Langerhans secondary to decrease the activities of lysosomal enzymes as cathepsin B and acid phosphatase, ${ }^{[30,31]}$. These cells are more susceptible to endoplasmic reticulum stress because of their high secreting activities and low antioxidant capacities $^{[32]}$, which is in agreement to our findings. However, others reported that patulin had hyperglycemic effect due to increased glycogen phosphorylase, glucose 6-phosphatase and fructose 1, 6 diphosphatase activities as well as decreased glycolytic enzymes as hexokinase and aldolase $\mathrm{e}^{[33]}$. Moreover, Asmat and colleagues stated that hyperglycemia can increase the lipid peroxidation, glycation of the lipoproteins and oxidative DNA damage of $\beta$ cells $^{[34]}$.

Lycium barbarum fruit (LB) or goji berry is a wellknown herbal medicine, has biological activities as reducing blood glucose and serum lipids ${ }^{[35]}$. Our results demonstrated that administration of its extract led to improvement of the pancreatic histological degenerative changes induced by patulin. Light microscopic examination showed that most of the acini and islets cells were more or less similar to the control group, conistent with the ultrastructural and immunohistochemical findings. There was a significant decrease in number of caspase- 3 positive cells in both acini and islet's of Langerhans attributed to its antioxidant components, such as thiamine, ascorbic acid, carotene, riboflavin, nicotinic acid that can provide defense against free radicals damage. In accordance to this suggestion some studies demonstrated that LB polysaccharide increased the level of antioxidant enzymes as superoxide dismutase and glutathione peroxidase to protect against oxidative stress ${ }^{[36]}$. It was proved that its extract could decrease the oxidative stress and DNA damage through inhibition of lipid peroxidation $^{[37]}$. Since LB reduced the number of caspase-3 positive cells in both acini and islets of Langerhans, this suggests its antiapoptotic activity. A number of studies had found that LB can increase the expression of Bcl2 and decrease the expression of Bax and increase the ratio of $\mathrm{Bcl}-2 / \mathrm{Bax}{ }^{[38]}$. It was proved that $\mathrm{LB}$ could inhibit Jun N-terminal kinases pathway which activate apoptotic signaling by the upregulation of pro-apoptotic genes ${ }^{[39]}$. Furthermore, improvement of $\beta$-cells activity in the present work might be due to direct cytoprotective and indirect hypoglycemic effects of the extract. In concomitant to this hypothesis it was reported that goji caused significant decrease in the fasting blood glucose and malondialdehyde levels in streptozotocin-induced rat diabetes ${ }^{[40]}$. The mechanism of its hypoglycemic effect remains controversy. Previous studies proved that goji extract could increase the liver and muscle glycogen which is the best storage form of glucose ${ }^{[41]}$. Moreover, LB polysaccharides could enhance the glucose transport in skeletal muscle by facilitating the translocation of glucose transporter 4 (the main insulin sensitive glucose transporter) from the cytoplasm to the cell membrane ${ }^{[42]}$. In addition, goji berry had the ability to reduce the level of tumor necrosis factor- $\alpha$ elevated by patulin and consequently led to increased cellular glucose uptake and inhibition of transient insulin resistance ${ }^{[43]}$.

\section{CONCLUSION}

This work provides an evidence of the toxic effect of patulin exposure on the pancreatic tissue. The use of goji extract could improve patulin injuries. It is recommended to be added in the manufacture of apple juice and the other apple products. Future studies should be done to determine the potential ingredient of goji extract that has this protective effect. 


\section{CONFLICT OF INTEREST}

There are no conflicts of interest.

\section{REFERENCES}

1. Morales H, Sanchis V, Coromines J, Ramos $\mathrm{AJ}$, Marin S. Inoculum size and intraspecific interactions affects Penicillium expansum growth and patulin accumulation in apples. Food Microbiol. 2008 Apr; 25(2):378 -85.

2. Puel, O., Galtier, P. and Oswald, I.P. Biosynthesis and toxicological effects of patulin. Toxins, 2010; 2: 613-31.

3. Harris K.L., Bobe G. and Bourquin L.D. Patulin surveillance in apple cider and juice marketed in Michigan. Journal of Food Protection (2009) 72(6): 1255-1261.

4. Al-Hazmi, M. A. Patulin in apple juice and its risk assessments on albino mice. Toxicology and industrial health, 2014; 30(6), 534- 545

5. Selmanoglu G., Kockaya E.A. Investigation of the effects of patulin on thyroid and testis, and hormone levels in growing male rats. Food Chem. Toxicol. 2004; 42:721-727.

6. Silva S., Schuch P.Z., Bernardi C.R., Vainstein M.H., Jablonski A. and Bender R.J. Patulin in food: state-of-the-art and analytical trends. Rev Bras Frutic 2007; 29: 406-413.

7. Sabino M. Detection and determination of patulin in fruits and fruit products. Mycotoxins in Fruits and Vegetables (Rivka B-G \& Nachman P, eds), 2008; pp. 261-270. Academic Press, San Diego, CA.).

8. Zhou, S. M., Jiang, L. P., Geng, C. Y., Cao, J., \& Zhong, L. F. Patulin-induced oxidative DNA damage and p53 modulation in HepG2 cells. Toxicon, 2010; 55(2), 390 -395.

9. Chandra, J., Samali, A., \& Orrenius, S. Triggering and modulation of apoptosis by oxidative stress. Free Radical Biology and Medicine, 2000; 29(3), 323 -333.

10. Meier, P., Finch, A., Evan, G., Apoptosis in development. Nature 2000; 407, 796-801.

11. Nicholson, D.W., Caspase structure, proteolytic substrates and function during apoptotic cell death. Cell Death Differ. 1999; 6, 1028-1042.
12. Janicke, R.U., Spregart, M.L., Wati, M.R. and Porter, A.G. Caspase-3 is required for DNA fragmentation and morphological changes associated with apoptosis. J. Biol. Chem. 1998; 273, 9357-9360.

13. Nicholson, D.W. and Thornberry, N.A. Caspases: killer proteases. Trends Biochem. Sci. 1997; 22, 299-306.

14. Fabricant DS, Farnsworth NR. The value of plants used in traditional medicine for drug discovery. Environ Health Perspect. 2001; 109 (Suppl 1):69-75.

15. Li, Q.Y. Healthy Functions and Medicinal Prescriptions of Lycium barbarum (Gou Ji Zi). Jindun Press, Beijing, 2001; pp. 1-16.

16. Luo, Q., Li, J., Cui, X., Yan, J., Zhao, Q., Xiang, C. The effect of Lycium barbarum polysaccharides on the male rats' reproductive system and spermatogenic cell apoptosis exposed to low-dose ionizing irradiation. Journal of ethnopharmacology, 2014; 154(1), 249- 258.

17. Cai, Y.Z., Luo, Q., Sun, M., Corke, H. Antioxidant activity and phenolic compounds of 112 traditional Chinese medicinal plants associated with anticancer. Life Sciences 2004; 74, 2157-2184.

18. Nagwa, M.E., Madeha N.Al-Seni, Nesreen G. Abd El Haliem, Mohamed T. El-Wassimy, H.Salah, Asma S.Abdo. Biochemical and Histological Studies of Goji Extract Role on Patulin Mycotoxin on Male Rat Kidney. Int J Food Nutr Sci. 2015; 2(4): 1 -7.

19. Bancroft JD, Gamble M. Theory and practice of histological techniques. $6^{\text {th }}$ ed. Philadelphia: Churchill Livingstone, Elsevier; 2008. pp. 126, 150,440

20. Chen N, Unnikrishnan IR, Anjana RM, Mohan V, Pitchumoni CS. The complex exocrine-endocrine relationship and secondary diabetes in exocrine pancreatic disorders. J Clin Gastroenterol. 2011;45:850-861

21. Fraga, C G, and Tappel. A L "Damage to DNA Concurrent with Lipid Peroxidation in Rat Liver Slices." Biochemical Journal 252.3 1988; 893896.

22. Saxena, N., Ansari, K. M., Kumar, R., Dhawan, A., Dwivedi, P. D., \& Das, M. Patulin causes DNA damage leading to cell cycle arrest and apoptosis through modulation of Bax, p 53 and p 21/WAF1 
proteins in skin of mice. Toxicology and applied pharmacology, 2009; 234(2), 192- 20

23. El-Sawi, N. M., Gashlan, H. M., Younes, S. H., Al-Massabi, R. F., \& Shaker, S. Biochemical and histological studies on the effect of the Patulin mycotoxin on male rats' liver and treatment by crude venom extracted from jelly fish. Life Science Journal, 2012; 9(4) 1143:1153.

24. Saxena N., Ansari M., Kumar R., Chaudhari BP., Dwivedi PD., and Das M. Role of mitogen activated protein kinases in skin tumorigenicity of Patrin. Toxicol Appl Pharmacol. 2011; 257: 264-271.

25. Sabino M. Detection and determination of patulin in fruits and fruit products. Mycotoxins in Fruits and Vegetables (Rivka B-G \& Nachman P, eds), 2008; pp. 261-270. Academic Press, San Diego, CA.

26. Mahfoud, R., Maresca, M., Garmy, N., \& Fantini, $\mathrm{J}$. The mycotoxin patulin alters the barrier function of the intestinal epithelium: mechanism of action of the toxin and protective effects of glutathione. Toxicology and applied pharmacology, 2002; 181(3), $209-218$.

27. El-Gamal, D. A., and Ghafeer, H. H. Histological changes in adult rat pancreas upon chronic administration of aspartame. Egyptian Journal of Histology, 2012; 35(4), 883 -891

28. Riley, R.T and Showker, J.L. The mechanism of patulin's cytotoxicity and the antioxidant activity of indole tetramic acids SciTech Connect (Toxicology and Mycotoxins Research Unit, U.S. Department of Agriculture/Agricultural Research Service, Athens, GA (USA) 1991,109:1. doi:10.1016008-0041/X(91)90195-K

29. Yule, D. I. Ca2+ Signaling in Pancreatic Acinar Cells. Pancreapedia: The Exocrine Pancreas Knowledge Base., DOI: 10.3998/panc.2015.24

30. Nisr, R. B., Russell, M. A., Chrachri, A., John Moody, A., \& Gilpin, M. L. Effects of the microbial secondary metabolites pyrrolnitrin, phenazine and patulin on INS-1 rat pancreatic $\beta$-cells. FEMS Immunology \& Medical Microbiology, 2011; 63(2), 217 -227.

31. Devaraj, H., Shanmugasundaram, K.R., and Shanmugasundaram, E.R.B. Role of patulin as a diabetogenic lactone, Indian Journal of Experimental Biology, 1986; 24: 458-459.
32. Fonseca SG, Urano F, Burcin M, Gromada J. Stress hyperactivation in the $\beta$-cell. Islets 2010; 2:1-9.

33. Wouters MFA and Speijers GJA Toxicological evaluations of certain food additives and contaminants in food: Patulin. WHO Food AD 1995; 35: 377-402.

34. Asmat, U., Abad, K. and Ismail, K. Diabetes mellitus and oxidative stress-a concise review. Saudi Pharmaceutical Journal, 2016; 24(5), 547.553-

35. Luo, Q., Cai, Y., Yan, J., Sun, M., \& Corke, H. Hypoglycemic and hypolipidemic effects and antioxidant activity of fruit extracts from Lycium barbarum. Life sciences, 2004; 76(2), 137- 149.

36. Shan X, Zhou J, Ma T, Chai Q. Lycium barbarum polysaccharides reduce exercise-induced oxidative stress. Int J Mol Sci. 2011; 12:1081-1088. doi: 10.3390/ijms12021081.

37. Ma M, Lui G, Yu Z, Chen G, Zhang X. Effect of the Lycium barbarum polysaccharides administration on blood lipid metabolism and oxidative stress of mice fed high-fat diet in vivo. Food Chem. 2009; 113:872-7.

38. Zhang, C., Wang, A., Sun, X., Li, X., Zhao, X., Li, S., \& Ma, A. Protective effects of Lycium barbarum polysaccharides on testis spermatogenic injury Induced by bisphenol A in mice. EvidenceBased Complementary and Alternative Medicine. 2013; doi.org/10.1155690808/2013/.

39. Li, H., Liang, Y., Chiu, K., Yuan, Q., Lin, B., Chang, R. C. C., \& So, K. F. Lycium barbarum (wolfberry) reduces secondary degeneration and oxidative stress, and inhibits JNK pathway in retina after partial optic nerve transection. PLoS One, 2013; 8(7), e68881.

40. Bucheli P, Gao Q, Redgwell R, et al. Biomolecular and Clinical Aspects of Chinese Wolfberry. In: Benzie IFF, Wachtel-Galor S, editors. Herbal Medicine: Biomolecular and Clinical Aspects. 2nd edition. Boca Raton (FL): CRC Press/Taylor \& Francis; 2011. Chapter 14.6. ANTIDIABETIC ACTIVITY OF WOLFBERRY.

41. Wu M. and Guo L." Anti-Fatigue and Anti-Hypoxic Effects of Lycium barbarum Polysaccharides ", International Conference on Advances in Energy, Environment and Chemical Engineering. 2015; pp. 686689-, doi:10.2991/aeece-15.2015.137 
42. Zhao, R., Li, Q., and Xiao, B. Effect of Lycium barbarum polysaccharide on the improvement of insulin resistance in NIDDM rats. Yakugaku Zasshi, 2005; 125(12), 981 -988.
43. Cai H., Liu F., Zuo P., Huang G., Song Z., Wang T., Lu H., Guo F., Han C. and Sun G. Practical Application of Antidiabetic Efficacy of Lycium barbarum Polysaccharide in Patients with Type 2 Diabetes. Medicinal Chemistry, 2015;11(4):383- 90 
الملخص العربى

هل يستطيع مستخلص توت القوجي التقليل من التغيرات الهستولوجية فى البنكرياس المسبية بسم الباتيولين فى ذكور الجرذان البيضاء ؟

نسرين جمال الدين عبا الحليم

قسم الهستولوجيا، كلية الطب ، جامعة سوهاج

المقدمة: يعتبر الباتيولين من السموم الفطرية الأكثر شيو عا في الفو اكة المتعفنة وخاصة التفاح و المنتجات المشتقة مثل عصير

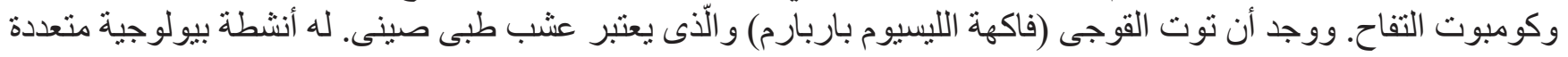

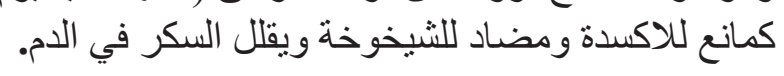

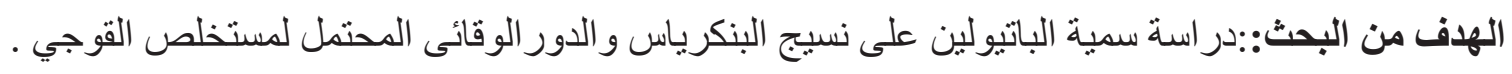

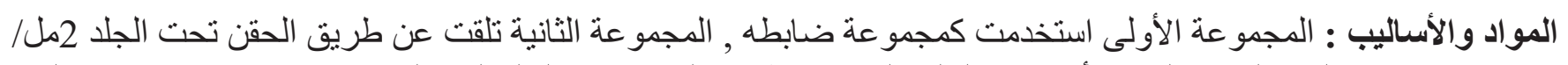

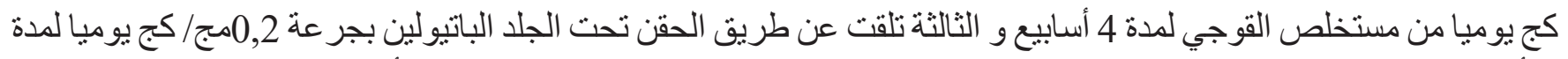

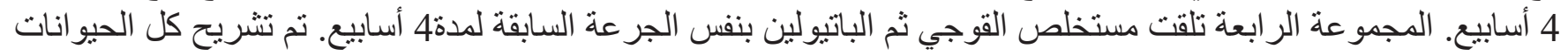

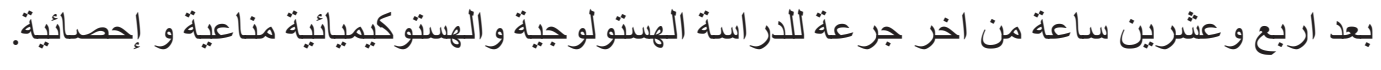

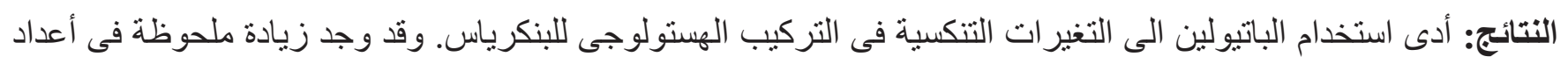

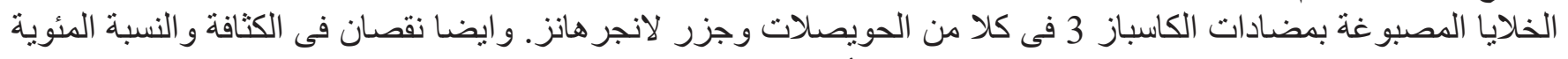

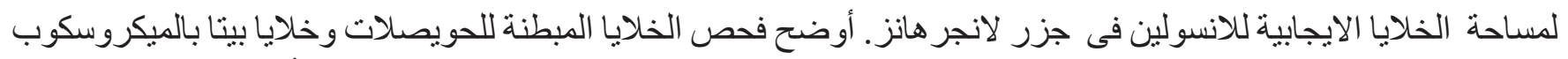

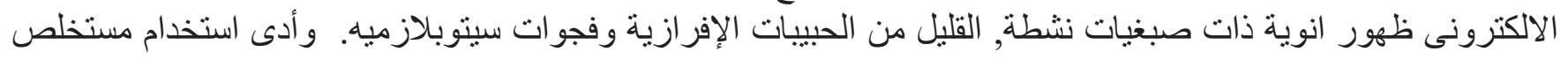

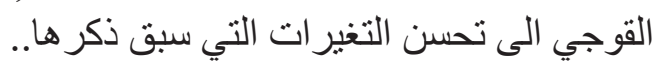
لإستنتاج: أن للباتيولين نأثثر سمى على الحويصلات وخلايا بيتا بجزر لانجرهانزز و ومستخلص القوجي له تأثثر وقائى على تلك السميا. 